\title{
Jak psát kvalitativně orientované výzkumné studie. Kvalita v kvalitativním výzkumu ${ }^{1}$
}

\author{
Klára Šed’ová, Roman Švaříček \\ Masarykova univerzita, Filozofická fakulta, Ústav pedagogických věd
}

Redakci zasláno 13. 5. 2013 / upravená verze obdržena 22. 7. 2013 / k uveřejnění přijato 23. 7.2013

\begin{abstract}
Abstrakt: Cílem této metodologické studie je definovat základní pravidla dobré kvalitativně orientované empirické studie, to znamená výzkumné zprávy prezentující výsledky kvalitativního výzkumného šetření, která je určena k publikaci v odborném vědeckém časopise. Sdílíme přitom odstup vůči jednoznačně formulovaným kritériím kvality kvalitativního výzkumu, která mohou omezovat autonomii výzkumníka v rozhodování o vlastních postupech. Naše pravidla je proto třeba vnímat jako rámcová doporučení, která umožní autorovi udržet kontrolu nad kvalitou vlastního výzkumu. Uváděná pravidla se vztahují ke čtyřem klíčovým oblastem výzkumné zprávy: věnujeme se (1) teoretickému rámci studie, (2) popisu plánu a prủběhu výzkumu, (3) výstupům z analýzy a interpretaci dat a (4) jazyku a stylu psaní výzkumné zprávy. Postupně definujeme 16 základních pravidel kvalitativního psaní, která vykládáme za pomoci metodologické literatury a komentovaných př́kladů z publikovaných i nepublikovaných kvalitativních studií. Domníváme se, že uvedená pravidla lze doporučit začínajícím autorům odborných vědeckých textů určených pro recenzované pedagogické časopisy jako základní vodítka.
\end{abstract}

Klíčová slova: kvalita kvalitativního výzkumu, kvalitativní výzkum, kritéria kvality, akademické psaní

Otázka kvality vědeckého výstupu zaměstnává kvalitativní výzkumníky již více než půl století a za tu dobu prošel pohled na kvalitu dramatickými změnami. Sociálně vědní badatelé se snaží definovat taková kritéria, která by spolehlivě určila kvalitní, validní, objektivní a platný výzkum. Navzdory velkému úsilí mnoha autorů však můžeme konstatovat, že ohledně kritérií kvality v kvalitativním výzkumu nepanuje jasný konsenzus.

Koncept validity a reliability již dlouho postrádá schopnost adekvátně postihnout širri fenoménů zkoumaných v kvalitativním výzkumu (Seale, 1999),

1 Tento článek vznikl v rámci projektu Učitel a žáci v dialogickém vyučování financovaného Grantovou agenturou České republiky (GA13-23578S). Autoři děkují za poskytnutou podporu. 
a proto jsme $\mathrm{v}$ posledních letech zaznamenali neuvěřitelný nárůst nových kritérií, která by měla posoudit kvalitu kvalitativního výzkumu. V přemíře nových termínů, které se často dublují, najdeme např́klad: imperiální validitu, ironickou validitu, situovanou validitu, neopragmatickou validitu, rhizomatickou validitu, zjevnou validitu, instrumentální validitu či teoretickou validitu (více viz Altheide \& Johnson, 1994). Bujení nových pojmů odráží těžkosti, s jakými se musí potýkat kvalitativní metodologové, kteří se upnuli k vytváření všezastřešujícího systému posuzování kvality. To ostře kontrastuje se situací podobně zaměřených autorů kvantitativní tradice, kde má obecná shoda o některých konceptech delší trvání. Snaha po definování základních kritérií kvalitativního výzkumu selhala zejména z toho důvodu, že neexistuje nic takového jako jednotné pojetí kvalitativního výzkumu.

Existuje několik odlišných tradic, zjednodušeně označovaných jako designy, jejichž metodologické postupy se zásadně liší. Liší se také náhledy na kvalitu podle geografického původu autorů. Zatímco badatelé $\mathrm{v}$ Evropě se dále snaží transformovat koncept validity a reliability tak, aby byl využitelný i v kvalitativním př́stupu (viz např. Hammersley, 2007), výzkumníci ve Spojených státech a Kanadě tvrdí, že kvalitativní výzkum je fundamentálně odlišný od kvantitativního, a proto nelze uplatňovat stejné požadavky (Guba \& Lincolnová, 2005; Morse et al., 2002). ${ }^{2}$

Obecně lze říci, že při hledání kvality a mechanismů její kontroly vždy existuje tenze mezi konvencionalizací a inovací (Freeman et al., 2007). Konvencionalizací rozumíme snahu preskriptivně stanovit určité postupy, které je třeba dodržovat, aby byla zaručena korektnost celého výzkumu. Inovace naopak znamená vůli ponechat metodologická rozhodnutí co nejvíce v režii samotného výzkumníka, který má vynalézat postupy co nejadekvátněji odpovídající jeho výzkumnému problému a povaze nasbíraných dat. Jak uvádějí Freeman et. al. (2007) ani jedna z těchto cest není bez nebezpečí. Přehnaný důraz na konvencionalizaci vede k bezduchému opakování ortodoxních postupů, nedostatečný důraz na konvencionalizaci vede naopak k módním vlnám, k nedostatku kontinuity a k fragmentarizaci dosahovaného poznání.

V 80. letech došlo ve Spojených státech k odmítnutí reliability a validity, které byly nahrazeny konceptem hodnověrnosti kvalitativního výzkumu (trustworthiness), který zahrnuje důvěryhodnost, přenositelnost, spolehlivost a potvrditelnost (Guba \& Lincoln, 1981). Hlavním důvodem byl požadavek, aby nová kritéria postihla celou šíri kvalitativního výzkumu, který má řadu různých variant - formálních i obsahových. Kvalitativní výzkum také často zpochybňuje dané (postupy, teorie, hodnoty), a proto jej není možné posuzovat za pomoci tradičních konceptů. Ačkoliv se jednalo o provizorní kritéria, návrh Guby a Lincolnové se zakrátko stal standardem pro posuzování kvality kvalitativního výzkumu. 
Snaha o důslednou konvencionalizaci vede ve svém důsledku k vytváření seznamů kritérií. S inspirací v pedagogice založené na důkazech (evidencebased education) tak vznikají dlouhé zaškrtávací seznamy určené pro posouzení kvality výzkumu. Kitto a jeho kolegové (2008) ukazují, jak seznam kritérií indikujících kvalitní vedení rozhovorů a ohniskových skupin díky této snaze stále narůstá, z původních 22 na 32 položek.

Proti tomu se vymezuje prŕístup označovaný jako postpozitivistický, který razí tendenci spíše než preskriptivně stanovovat závazná kritéria studovat postupy, které výzkumníci reálně používají, následně posuzovat jejich výsledky a dále povzbuzovat výzkumníky k rozvíjení těch postupů, které jsou shledávány jako excelentní.

Klasik pedagogického kvalitativního výzkumu M. Hammersley (2007, s. 300) dodává, že namísto seznamů kritérií je užitečnější vytvářet doporučení, která umožní výzkumníkovi udržet kontrolu nad kvalitou vlastního výzkumu, ale zároveň jej nezbavují autonomního rozhodování o vlastních postupech.

\section{Kvalita ve výzkumu, kvalita v textu?}

Velmi obecně lze říci, že se dnes metodologové kloní k tomu názoru, že kvalitu v kvalitativním výzkumu zaručují dvě věci: zaprvé pečlivá práce v průběhu výzkumu a zadruhé korektní podoba výsledné výzkumné zprávy. Stále platí, že bez dodržování určitých pravidel se z vědy stává spekulativní fikce. Do procesu hledání a posuzování kvality se přitom nezapojují jen sami výzkumníci a autoři, zodpovědnost při posuzování kvality je také na redakčních radách a recenzentech odborných časopisů, které výsledky výzkumů publikují, a také na samotných čtenářích, již jsou rovněž členy odborné komunity. Pravdivost a platnost výzkumu je tedy vyjednávána, je spíše výsledkem konsenzu nad každou jednotlivou závěrečnou studií než aplikováním sady kritérií či položek ze sáhodlouhých seznamů základních požadavků.

Ve vnímání kvality kvalitativního výzkumu tak došlo k posunu směrem k posuzování samotných výzkumných zpráv. Empirické sdělení musí být podrobeno kritice vědecké komunity (Kuhn, 1997, s. 29), z čehož vyplývá, že produkce nových teorií nemůže být oddělena od způsobu, jakým jsou poznatky sdělovány komunitě čtenářů, kteří zpětně rozhodují o platnosti daného výzkumu. Vyprávění o zkoumané realitě je prostředkem k vytváření poznání o realitě, a proto nelze od sebe oddělit výzkum a publikaci výsledků, produkci a sdělování poznatků (Shapin, 1984). V této studii je naším primárním cílem 
vyjadřovat se ke kvalitě textů prezentujících výsledky kvalitativních šetření, přesto na některých místech bude debata poněkud zabíhat ke kvalitě výzkumů, jež jsou podkladem těchto textů. Důvodem je právě výše uvedený fakt, že jedno od druhého nelze zcela separovat. Kvalitu výzkumu vůbec nemůžeme posuzovat bez toho, že bychom se s ním seznámili prostřednictvím publikace výsledků. A co je nejpodstatnější: dobrý článek lze jen stěží napsat na základě nekvalitně provedeného výzkumu.

Autoři výzkumných zpráv vycházejících z kvalitativního výzkumu používají ke sdělení často expresivní vyjádření, citace plné nespisovného jazyka a argotu, někdy též volí nestandardní prezentační postupy, jako jsou báseň (Furman et al., 2007) či dramatizace, aby vyjádřili příběhy z terénu (VanMaanen, 1988) plné hustého popisu a intimního vhledu. K posouzení takto nestandardních textů bychom potřebovali další sadu kritérií, nejen epistemologická a metodologická kritéria, o kterých byla dosud řeč, ale také např́iklad kritéria estetická.

Ellisová (2000), propagátorka užívání estetických kritérií při posuzování výzkumných zpráv, požaduje, aby př́běhy v kvalitativně orientovaných výzkumech umožnily čtenáři plně se ponořit do jiného světa, aby s ním příběhy zůstaly, i když je přestane číst. Př́iběhy by měly mít dobrý scénář, dramatické napětí, logickou konzistenci a autenticitu prožitku. Autoři dobrých textů by měli ukázat, nikoliv jen popsat, že vytvořili nový svět plný bohatě rozvinutých postav. Podobně Bochner (2000) vytvořil celkem sedm kritérií, která umožňují hodnotit poetičnost sociálně vědního světa. Zdůrazňuje tak například konkrétní detaily, strukturální komplexnost vyprávění, emocionální důvěryhodnost, morální závazek a další.

Tento posun směrem ke zcela novým hodnoticím parametrům se může zdát poněkud výstřední, platí však, že dochází k velkému rozrůznění kvalitativních kritérií. Otázky pravdivosti a důvěryhodnosti jsou nyní posuzovány především podle specifických kritérií, která jsou adekvátní určitému konkrétnímu výzkumnému designu (jiná kritéria jsou uplatňována v etnografii, jiná v narativním výzkumu), či která jsou posuzována dle odlišných ideových východisek (jiná kritéria jsou sledována ve feministicky zaměřených studiích a při posuzování estetické hodnoty výzkumné zprávy).

V následujícím textu se chceme vyjádřit k otázce, co by měl obsahovat dobře napsaný text prezentující výsledky kvalitativního výzkumu. Sdílíme odstup 
vůči tvrdě formulovaným kritériím a požadavkům (viz výše). Proto jsme se rozhodli v následujícím výkladu jít cestou doporučení, provést čtenáře po čtyřech klíčových oblastech, které jsou pro redaktory, recenzenty a čtenáře podstatné při posuzování kvality textu a potažmo celého výzkumu, který za textem stojí. Vycházíme přitom jak ze studia odborné literatury, tak ze zkušeností s působením ve výkonné redakci pedagogického časopisu, stejně jako ze zkušeností získaných při vedení studentských prací. Nebudeme se tedy zabývat tím, jak realizovat dobrý kvalitativní výzkum ${ }^{3}$, ani nebudeme vytvářet další kritéria či spojovat dosavadní kritéria v nové seznamy ${ }^{4}$, nýbrž se pokusíme nabídnout vodítka, jak dobře prezentovat (dobře provedený) kvalitativní výzkum.

\section{Jak popsat teoretický rámec}

V následujících dvou kapitolách se budeme věnovat tomu, jak popsat teoretický rámec a plán výzkumu spolu se sběrem dat. Při rozsahu článku o 20 stranách by teorie měla tvořit čtyři až pět stran, popis metodologie dvě až tři strany, analýza a interpretace dat deset stran a diskuse se závěrem dvě až tři strany.

Prvním pravidlem při tvorbě kvalitativního článku je zaujmout čtenáře dobře strukturovaným abstraktem (ten ovšem paradoxně při psaní vzniká obvykle jako poslední). Abstrakt článku je vedle názvu příspěvku rozhodující pro to, zda si čtenář text přečte či nikoliv. Některé publikace věnované odbornému psaní uvádějí, že nejdůležitější je první věta, ale v dnešní záplavě odborných textů a knih je to právě abstrakt, podle kterého text odhadujeme. Abstrakt by měl zaujmout čtenáře tím, že jasně pojmenuje zkoumaný fenomén, metody práce a výsledky výzkumu. Pro ilustraci se můžeme podívat na abstrakt článku Smetáčkové (2011), který byl v roce 2012 druhým nejčtenějším v elektronickém archívu časopisu Studia paedagogica.

\section{Př́́KLAD Z VÝZKUMNÉ ZPRÁVY 1}

V životě dětí a jejich rodičủ představuje škola v mnoha směrech významnou instituci, nebot' hluboce strukturuje jejich život. To se promítá mimo jiné i do

\footnotetext{
Techniky pro zabezpečení kvality v průběhu výzkumu popisujeme jinde (Švaříček, 2007). 0 etických kritériích pedagogického výzkumu viz Průcha \& Švaříček (2009).

4 Domníváme se, že vytvářet další kritéria či spojovat dosavadní kritéria v nové seznamy není př́liš užitečné. Jednak jsme již uvedli, že slepé aplikování některých technik nezaručuje kvalitu (Rolfe, 2004), jednak pochybujeme o užitečnosti sady položek pro začínající badatele a autory.
} 
obsahu komunikace mezi rodiči a dětmi. Článek se zaměřuje na otázku, které školní zážitky žáci a žákyně na konci základní školy sdílejí se svými rodiči, jakou má toto sdílení formu a jaký význam mu žáci přikládají. Prezentovány jsou výsledky výzkumného šetření, které zahrnovalo hloubkové rozhovory s 16 žáky a dále dotazník pro 424 respondentů. Výsledky naznačují, že děti třídí údaje o škole do několika skupin, které od sebe odlišují nejen tematicky, ale zejména mírou nároku, který rodiče na znalosti daných informací mají. Článek dále popisuje konkrétní strategie, které děti při komunikaci s rodiči o škole užívají. (Smetáčková, 2011, s. 9)

Článek s názvem Škola jako téma rozhovorů mezi dětmi a rodiči popisuje komunikaci mezi rodiči a dětmi, což je téma pedagogickým výzkumem relativně opomíjené. Uvedený abstrakt je otevřen sdělením, že škola je jedním z důležitých témat komunikace mezi rodiči a dětmi. V abstraktu je jasně uvedena základní otázka, která se v textu řeší (které školní zážitky...), a rovněž užité výzkumné metody. Nato autorka přechází k výsledkům, přičemž neslibuje jen jednoduché pojmenování různých témat, o nichž rodiče s dětmi vedou řeč, nýbrž avizuje rozpracování teorie o míře nároků vznášených rodiči na různé typy informací a s tím spojenými dětskými komunikačními strategiemi. Poslední věta působí jako pozvání čtenáře k rozluštění nějakého tajemství. Citovaný abstrakt tak nejen obsahuje všechny podstatné informace, ale je též lákavý.

Druhým pravidlem je nutnost uplést tenkou červenou nit, která se bude prolínat celým článkem. Tuto nit začínáme plést $\mathrm{v}$ úvodních pasážích článku, kde je třeba vyložit čtenáři několik jednoduchých věcí: o čem článek bude, proč je v kontextu dané vědecké disciplíny významný, jaké nálezy budou představeny, případně jaké teorie budou rozvíjeny a jak bude text strukturován. Opomenutí těchto otázek přináší riziko nepochopení autorského sdělení čtenářem textu. Ačkoli je autorským cílem přitáhnout čtenářskou pozornost, doporučujeme držet se věcného tónu - to znamená nestavět do popředí osobní zaujetí či angažovanost autora, ani si moralistně nestěžovat na to, jak je škoda, že se danému tématu nikdo (kromě autora) nevěnuje. Nechme v těchto pasážích do popředí vystoupit téma samotné.

Nepovinnou součástí úvodu je představení epistemologických východisek autora výzkumu. Jedná se o reflexi subjektivity, reflexi ideového pozadí článku, což by mělo čtenáři usnadnit pochopit vyprávěný příběh. V knižních publikacích může být reflexi subjektivity věnována samostatná kapitola - 
například Katrňák (2004) takovou kapitolu umist’uje na závěr své kvalitativní monografie o vzdělanostní reprodukci $v$ dělnických rodinách a označuje ji jako Apendix A. Je však možné se v článcích s jejich omezeným prostorem $\mathrm{k}$ problematice východisek vyjádřit? Jako pozitivní př́klad můžeme uvést text Čálka (1995), který ve svém patnáctistránkovém článku o zkoušení žáků na základní škole píše, že je nezbytné popsat skrze sebereflexi svoje předpojaté názory, nebot' není možné do prostoru školy vstoupit s neutrálním očekáváním. Proto popisuje svoje názory o nezbytnosti systému zkoušení a náročné zátěži při zkoušení, kterou lze využít ke zvyšování odolnosti žáků, čehož by měli být schopni kvalitní učitelé.

Domníváme se, že není nutné přímo do úvodu článku zařadit oddíl věnující se epistemologickým či filozofickým pojetím autora textu, avšak považujeme za nezbytné, aby text obsahoval dobře popsaný teoretický rámec. Teoretický rámec je zároveň interpretačním nástrojem, který čtenáře vede k jistému typu interpretací ohledně toho, co se odehrává v daném zkoumaném prostředí. Tento rámec by měl čtenáře přesvědčit o tom, že to, co se může jevit jako soubor nahodilých a nesourodých prvků, lze vysvětlit skrze konzistentní myšlenku. Existují dva základní pohledy na přínos teorie - jeden říká, že teorie by měla podávat vysvětlení př́ćcin určitých jevů a předpovídat budoucí stav (Hammersley, 1992), zatímco druhý se staví proti tomuto kauzálnímu pojetí a říká, že teorie by měla mít podobu vhledu a interpretování, které nutně nenabízejí jednoduché výkladové schéma (Ball, 1991, s. 188). Oba tyto př́stupy jsou v kvalitativním výzkumu uznávány.

Psaní je osamělá činnost, kterou zpravidla předchází další osamělá aktivita, kterou je čtení odborných knih a článkủ. V kvalitativním výzkumu je do jisté míry zakořeněn mýtus, podle něhož bychom před vstupem do terénu neměli číst žádnou literaturu. Nesmyslnost tohoto tvrzení již byla opakovaně vyvrácena (Glaser, 1978, s. 31).

Domníváme se, že je naopak nezbytné, aby badatel byl dobře obeznámen $\mathrm{s}$ dostupnou literaturou ke zkoumanému tématu. Teoretický rámec slouží $v$ prvé řadě autorovi výzkumu jako zdroj nápadů a podnětů pro realizaci šetření (Woods, 2006, s. 23), ačkoli v kvalitativním výzkumu se literatura ve fázi plánování vlastního šetření využívá jiným způsobem než ve výzkumu kvantitativním - dochází spíše k hledání bílých míst; hledáme fenomény, jež nejsou dostatečně vysvětlené nebo nás vysvětlení dostupná v literatuře neuspokojují. Vedle toho, jak již bylo řečeno, autor prostřednictvím prezentovaných 
teoretických východisek navádí čtenáře na jisté typy vysvětlení vlastních nálezů. Jinými slovy: teze obsažené v teoretickém rámci jsou v dobré kvalitativní studii využívány také při interpretaci dat ve výsledkové části (viz dále).

Teoretický rámec musí být vystavěn na základě důkladné rešerše literatury. Odkazované publikace by neměly působit eklekticky, což bývá často důsledkem povrchního hledání zdrojů dostupných na internetu, a vyvolává to dojem nezakotvenosti autora v oboru. Častým nešvarem je opomíjení současné časopisecké produkce (zahraniční, ale překvapivě též české), což nesvědčí kvalitě textu, a bývá to logicky často předmětem kritiky ze strany recenzentů. Doporučujeme proto vyjít v prvé řadě z Analytického katalogu Národní knihovny $\check{C} R{ }^{5}$ který obsahuje soupis všech českých časopiseckých článků. Na základě seznamu jejich zdrojů můžeme v druhém kroku přejít $\mathrm{k}$ vyhledávání $\mathrm{v}$ katalogu jakékoliv vědecké knihovny ${ }^{6} \mathrm{a} v$ zahraničních elektronických zdrojích ${ }^{7}$.

Teoretické pasáže v kvalitativní výzkumné studii musí v prvé řadě pokrýt základní koncepty, s nimiž budeme dále pracovat. Všechny užívané koncepty musí být $\mathrm{v}$ našem textu precizně definovány. Jako nadbíhání negativnímu recenznímu posudku můžeme označit postup, kdy autor pracuje s teoretickými koncepty, které jsou velmi široké (např. socializace, sociální učení, učení se pravidlům, internalizace pravidel, organizační učení) a nejsou pregnantně definovány s odkazem na primární zdroje (odkaz na učebnice nepostačuje).

Kupodivu teoretickému rámci nesvědčí ani to, je-li konceptů prŕliš mnoho. Smyslem teoretické části totiž není nahromadění myšlenek jiných autorů $\mathrm{k}$ danému tématu na jedno místo, s čímž se často setkáváme ve studentských pracích. Jedná se o zvláštní typ poučování čtenáře, jako by se autor snažil ohromit velkým množstvím zdrojů. Příkladem je ukázka z rukopisu nepublikované diplomové práce věnované dětské hře na základní škole. Autor v kapitole Teorie hry očima pedagogů klasiků za sebe vrství krátké výtažky o tom, co si o hře myslely oborové autority.

\footnotetext{
http://aleph.nkp.cz/F/

Dobrou službu poskytuje Jednotná informační brána (http://www.jib.cz/).

Mezi základní databáze patří: EBSCO (http://search.epnet.com), ERIC (http://www. eric.ed.gov/), JSTOR (http://www.jstor.org), ProQuest (http://search.proquest.com/), EducatiON-LINE (http://www.leeds.ac.uk/educol/BEID.html).
} 


\section{PŘíKLAD Z VÝZKUMNÉ ZPRÁVY 2}

H. Spencer vidí hru jako projev přemíry energie a zdroj veškerého umění. S. Hall vyslovil svou rekapitulační teorii, jejíž podstatou je názor, že dítě ve svých hrách rekapituluje vývoj lidstva. K. Groos rozvinul teorii hry označovanou jako nacvičování dovedností. Hra je podle něj chápána jako obecný impulz nacvičování instinktů, potřebných pro současný stav a budoucí život a je úzce spojena s napodobováním. Podle Freudova pojetí je hra promítnutím několika rušivých podnětů, se kterými se dítě snaží vyrovnat prostř̌ednictvím hraček a fantazijních představ. J. Piaget vyjadřuje úzkou souvislost mezi vývojem hry a rozvojem jeho myšlení a inteligence... (nepublikováno)

Tento postup není obhajitelný z několika důvodů: zaprvé jen povrchně naznačuje teoretické pojetí hry u daného autora, zadruhé není odkazováno na primární literaturu, a proto si nemůžeme být jisti autorstvím daného textu, zatřetí nám zkratkovité vyjádření neumožňuje ověřit správnost daného výroku a začtvrté obecné teze nejsou autorem práce nijak komentovány.

Třetím pravidlem při zpracovávání teoretického rámce je vyjít při výkladu z primárních zdrojů a každou citaci patřičně komentovat, doslova vytěžit její potenciál nejméně dvojnásobným množstvím vlastního textu. Výše uvedená ukázka může sloužit pro autora jako první orientační stupeň při zpřehlednění teoretického pozadí konceptu dětské hry, ale pro čtenáře neznamená žádný přínos.

Teoretický rámec má být teoretickým vymezením předmětu výzkumu umožňuje představit teorie, modely, schémata a hypotézy řešené $v$ dané oblasti. Mnozí autoři navazují na toto vymezení při popisu metodologie výzkumu, jak je vidět v následující ukázce vybrané z části článku, nazvané Metodologické poznámky.

\section{PŘíKLAD Z VÝZKUMNÉ ZPRÁVY 3}

Cílem realizovaných př́ípadových studií tedy bylo poznat a popsat, jaká je cesta od učení se jedincủ ve škole k organizačnímu učení (broadening), čeho se organizační učení v dnešních školách dotýká (deepening), jak jsou procesy tohoto učení ŕízeny a jaké existují ve školách podpůrné faktory a bariéry učení (anchoring). Výsledky př́padových studií se nám posléze staly východiskem druhé výzkumné fáze, dotazníkového šetření mezi učiteli a vedením škol. (Sedláček et al., 2012, s. 29)

Kolektiv autorů pod vedením M. Sedláčka v textu o organizačním učení školy nejprve $\mathrm{v}$ teoretickém rámci popsal třídimenzionální model organizačního učení od nizozemského autora E. Verbiesta (2011). Model byl vyvinut 
induktivně při dlouholetých výzkumných počinech Verbiesta a jeho kolegů a $\mathrm{v}$ uvedeném článku je využit $\mathrm{k}$ tomu, aby jeho autoři mohli čtenáři vědeckým způsobem vyložit jednoduché otázky, které je zajímají: kdo se učí (broadening), co se učí (deepening) a jaké podpory se mu dostává na dané škole (anchoring).

Čtvrtým pravidlem kvalitativního psaní je užívat vědecké koncepty tvůrčím způsobem. Tvưrčí princip by měl být vidět nikoliv v originálních názorech autora na to či ono, ale měl by být viditelný v popisu teoretických konceptů. Cílem je vyložit $s$ autorským komentářem definice daného jevu a vytvořit vlastní definici či alespoň vymezit vlastní postoj k převzatým definicím.

\section{PŘíKLAD Z VÝZKUMNÉ ZPRÁVY 4}

Př́kladem může být nepublikovaná diplomová práce o tvořivosti žáků druhého stupně základní školy. Při definování tvořivosti autor nejprve odlišuje termín tvořivost od termínu originalita, posléze konstatuje, že publikace o tvořivosti nejednou definici tvořivosti ani neobsahují, jiné jich naproti tomu obsahují až dvacet. Pro uspořádání všech definicí použije jednoduchou kategorizaci na čtyřri druhy tvořivosti - tvořivost jako schopnost jedince, tvořivost jako výsledný produkt činnosti, tvořivost jako výsledek pozitivních stimulů okolí a tvořivost jako proces. Uvedená kategorizace umožňuje základní rozčlenění, ve kterých se posléze jednotlivé definice dále komentují a prohlubují. Následně se autor hlásí $\mathrm{k}$ vymezení tvořivosti jako procesu, přičemž to patřičně zdůvodňuje. Tento postup pokračuje dalšími kapitolami s určením fází tvořivého procesu, tvořivého výkonu žáků a činitelů ovlivňujících tvořivý proces.

Druhým často používaným způsobem pro základní kategorizaci je pohled jednotlivých disciplín na daný jev. Příkladem může být filozofické, psychologické a pedagogické zkoumání tvořivého procesu. Autor musí být nejprve sám dokonale obeznámen s teorií, aby ji mohl uspořádat s pomocí (nových) abstraktních kategorií.

Pátým pravidlem je nasytit teoretický rámec popisem realizovaných empirických výzkumů zkoumaného jevu. Je dobré popsat v jednom či dvou odstavcích, co už bylo na dané téma vyzkoumáno v českém i zahraničním kontextu. Charakteristika provedených výzkumů slouží v neposlední řadě jako přemostění k další části textu, kterou je metodologická kapitola.

\section{PŘíKLAD Z VÝZKUMNÉ ZPRÁVY 5}

O vytvoření funkční typologie se pokusily Golishová a Olsonová (2000), které ve svém výzkumu požádaly 163 vysokoškolských studentů o zkonstruování zpráv, 
které by použili k modifikaci chování svého učitele tak, aby dosáhli svého záměru. Na základě získaného korpusu zpráv a jejich kategorizace pak byl vytvořen seznam 19 technik, které jsou chápány jako komplexní sada aktivních žákovských strategií realizovaných skrze komunikaci. (Makovská, 2011, s. 87)

Autorka článku o strategiích mocenského vyjednávání žáků na druhém stupni základní školy popisuje americký výzkum, jehož výsledkem byla typologie žákovských technik. Celá typologie technik změn chování je v následujícím textu článku představena čtenáři i s př́klady a jsou přiloženy kritické komentáře dalších autorů, aby si následně autorka položila otázku, nakolik je možné danou typologii využít při interpretaci dat z českého kontextu. Zahraniční výzkumy tak nejsou jen zmíněny výčtem, ale jsou nejprve pečlivě představeny, aby mohly být dále zpracovány tvůrčím způsobem při analýze dat.

\section{Jak popsat výzkumný proces}

Obligátní součástí každé výzkumné zprávy je metodologická část. Jejím cílem je popsat výzkumný plán (design), metody sběru dat, sledovaný vzorek, průběh výzkumu a způsob analýzy dat. Vzhledem k tomu, že článek zpravidla popisuje jen dílčí část celého výzkumu, je nutné obeznámit čtenáře $s$ tím, o kterou část výzkumu se jedná a jaká data budou předmětem analýzy. Čím více informací poskytneme čtenáři, tím srozumitelnější pro něj budou v další části prezentované výsledky výzkumu.

Výzkumný plán by měl být popsán tak, abychom mohli sledovat onu tenkou červenou nit linoucí se od teorie až k formulaci výzkumných otázek. Doporučujeme uvést hlavní i specifické výzkumné otázky, nebot' tento jednoduchý způsob umožní strukturovat naše myšlenky do podoby stravitelné pro čtenáře.

\section{PŘíKLAD Z VÝZKUMNÉ ZPRÁVY 6}

Hlavní výzkumná otázka, která vedla $\mathrm{k}$ interpretaci dat, zněla následovně: Jaké typy otázek učitelé ve vyučování kladou a jaké funkce plní tyto otázky ve výukové komunikaci? Při analýze jsme se dále drželi těchto specifických výzkumných otázek: Jaké typy otázek používají učitelé ve vybraných předmětech? Jak jsou jednotlivé druhy otázek zastoupeny v daných vyučovacích hodinách? Jak učitelé používají otevřené a uzavřené otázky? Jak je možné odlišit otázky podle míry kognitivní náročnosti? (Švaříček, 2011, s. 15) 
Uvedené výzkumné otázky potom mohou sloužit jako východisko pro členění podkapitol v části věnované analýze dat, kde popisujeme typy otázek, počty otázek, otevřené a uzavřené otázky, otázky nižší a vyšší kognitivní náročnosti, vliv počtu otázek na výukovou komunikaci a funkci vzdělávacích otázek učitele ve výukové komunikaci. Výzkumné otázky tak slouží nejenom autorovi výzkumu při analýze dat, ale i čtenáři poskytují základní orientaci o tom, odkud a kam směřuje výklad. Výzkumné otázky se v dramatické stavbě článku stávají jakýmsi prvním zvratem, ${ }^{8}$ který odděluje teorii od empirické části a kdy vyvrcholí tenká červená linie napojená na teoretický rámec. Šestým pravidlem kvalitativního psaní tak je rozvedení výzkumných otázek a jejich vysvětlení čtenáři, čímž tenká červená linie dostává explicitní konkretizaci v zacílených výzkumných otázkách.

Sedmým pravidlem je zdokumentovat průběh cesty, kterou badatel urazil, aby získal potřebná data. Čtenář nemůže posoudit výsledek výzkumu, aniž by přesně znal průběh výzkumu a průběh analýzy dat. Platí, že čím přesnější popis bude, tím větší bude pravdivost (Morse et al., 2002) výzkumné zprávy. V následující zkrácené ukázce je vidět narativní podoba této dokumentace pohybu výzkumníka v terénu. Postupně jsme seznámeni s tím, že výzkum probíhal dva roky, že jeho předmětem bylo skryté kurikulum mateřské školy, že role výzkumníka se proměňovala od pozorovatele $\mathrm{k}$ přímému účastníkovi školní výuky, že sběr dat probíhal skrze pozorování, které bylo zaznamenáváno ve formě terénního deníku, a kategorie vznikaly v průběhu sběru dat, kdy byla zároveň prováděna analýza.

\section{PŘíKLAD Z VÝZKUMNÉ ZPRÁVY 7}

Výskum sme realizovali počas dvoch po sebe nasledujúcich rokov (2005-2007) v dvoch prvých triedach jednej materskej školy. Počas tohto časového obdobia sme realizovali zúčastnené pozorovanie zamerané na skryté aspekty školskej socializácie. Naša rola sa v priebehu pobytu v materskej škole postupom času menila. Najskôr sme zaujímali pozíciu tzv. pozorovatela-účastníka, postupom času stráveného v prostredí školy a najmladšej triedy sme sa čoraz viac posúvali k pólu účastníka-pozorovatela [...] Zo začiatku sme sedeli pri poslednom detskom stolíku v triede, ked' sa skupina presúvala, chodili sme za ňou a pri každej činnosti sme sa snažili zaujat' také miesto, aby sme mali prehlad o dianí v triede a zároveň aby sme nezavadzali [...] nakoniec by sa dala naša pozice porovnat' s pomocnicou, ktorú mali učitel'ky v najmladšej skupine $\mathrm{k}$ dispozícii počas doobedných aktivít a ktorú zapájali do svojich hier i deti, no didaktických aktivít sa účastnila len zriedka [...] Záznamy diania v triede, opisy situácií, rozhovory a komentáre

\footnotetext{
8 Druhým dramatickým zvratem jsou odpovědi na výzkumné otázky.
} 
učiteliek sme zapisovali do terénnych zápiskov, ktoré sme opakovane analyzovali a hladali v nich jednotlivé kategórie a ich vzájomné vztahy. Postupovali sme od všeobecného, širokými a otvorenými kategóriami ohraničeného pozorovania až $\mathrm{k}$ výberovému pozorovaniu zameranému na potvrdenie či vyvrátenie niektorej kategórie. (Filagová, 2010, s. 51)

Velmi častou chybou při popisu výzkumného procesu a následně pak při analýze dat je krátké sdělení, že byla použita metoda polostrukturovaného rozhovoru, bez toho, že bychom se dozvěděli, jak bylo zkonstruováno tazatelské schéma a jakým způsobem byl rozhovor veden. Jen malá část autorů podrobně popisuje způsob, jakým otázky rozhovorů vznikly. Použili autoři pro rozhovory a tvorbu otázek pyramidový model (Wengraf, 2001), postupovali podle návodu Kvaleho (1996) či zcela jinak?

Osmým pravidlem, řečeno metaforicky, je představit čtenáři naše zkoumané jedince a seznámit jej s nimi. Musíme popsat výzkumný vzorek a vyjasnit, kdo a proč byl zkoumaným subjektem, jak byl výběr stanoven, abychom přesvědčili čtenáře o tom, že vzorek je vhodný vzhledem $\mathrm{k}$ výzkumným otázkám a že naši zkoumaní účastníci mají dostatečné znalosti a zkušenosti relevantní ve vztahu ke zkoumanému tématu.

Doporučujeme dále, aby bylo popsáno, jak nakládáme s informacemi od zkoumaných jedinců. Někteří autoři se domnívají, že zkoumaní jedinci nemohou pochopit plnost sociální situace, a proto ukazují jejich „nereflektovaný“ pohled na daný jev. Př́kladem je článek Filagové (2005) o vlivu učitelek na genderovou identitu dětí v mateřské škole. Ačkoliv učitelky v rozhovorech uvádí, že nedělají rozdíly mezi žáky podle pohlaví, Filagová na základě zúčastněného pozorování ukazuje pravý opak. Respondenti netematizují zkoumaný problém, a proto nejsou schopni reflektovat vlastní odlišné chování vůči dívkám a chlapcům. Výzkumník se stává tím, kdo rozhoduje o výsledné interpretaci reality, ř́kají autoři podobně pojatých výzkumů. Klasická podoba takového pohledu je následující: autor popisuje jednání jedince a ř́́ká, že jedinec pochopil (velmi často užívané slovo), že je např́íklad vnímán negativně kolegy či že jednal špatně. Primárním cílem výzkumu však není hodnocení jednání a myšlení jedinců, $\mathrm{v}$ tomto případě skryté do tvrzení o správném výkladu světa zkoumanými jedinci. 


\section{Jak popsat analýzu a interpretaci dat}

Jakýkoli typ analýzy kvalitativních dat zahrnuje několik úrovní práce s daty. Tyto úrovně na sebe navazují a tvořri jakýsi „žebřík“ vedoucí ke stále vyššímu stupni abstrakce (Miles \& Huberman, 1994, s. 224). Budeme-li vzestupně vyjmenovávat nejdůležitější příčky tohoto žebříku, dostaneme následující seznam operací: (1) třídění dat, jejich kódování a kategorizace; (2) formulace základních (jádrových) tvrzení; (3) interpretace; (4) komparace; (5) teoretická generalizace.

Na tomto místě není naším cílem popisovat náplň jednotlivých kroků, o té ostatně zevrubně informují učebnice kvalitativního výzkumu, nýbrž se zastavit u otázky, jakým způsobem se jednotlivé kroky odrazí ve výsledném textu. $V$ tabulce 1 ukazujeme, $v$ jakých částech textu autor odhaluje jednotlivé analytické kroky, a zároveň formulujeme základní pravidlo, jehož je třeba se v té které části držet.

Povaha kvalitativního výzkumu je cirkulární (srov. Flick, 2006, s. 100), to znamená, že se jednotlivé kroky překrývají, výzkumník se může vracet k již realizovaným krokům a revidovat je. Práce na jednotlivých úrovních tudíž nemusí jít př́močaře kupředu od bodu 1 do bodu 5 . Povaha psaného textu je nicméně lineární, nebot' čtenář postupuje větu po větě kapitolu za kapitolou. Proto lze při tvorbě článku dodržení posloupnosti, v níž jsou demonstrovány výsledky jednotlivých analytických kroků, doporučit.

Tabulka 1

Postup při prezentaci výstupů z analýzy dat

\begin{tabular}{|c|c|c|}
\hline Úroveň & Partie v textu & Pravidlo \\
\hline 1 & Datové úryvky & $\begin{array}{l}\text { Dobře ošetřit datové fragmenty v textu: vybrat úryvky, } \\
\text { které reprezentují klíčové kódy a kategorie, a logicky je } \\
\text { v textu seřadit. }\end{array}$ \\
\hline 2 & $\begin{array}{l}\text { Autorský text uvozující } \\
\text { datové úryvky, shrnutí, } \\
\text { závěr }\end{array}$ & Jasně formulovat jádrová tvrzení. \\
\hline 3 & $\begin{array}{l}\text { Autorská interpretace } \\
\text { datových úryvků }\end{array}$ & $\begin{array}{l}\text { Nabídnout rozpracovanou intepretaci toho, co se } \\
\text { v úryvcích ř́íá či děje. }\end{array}$ \\
\hline 4 & Vzniklé typologie & $\begin{array}{l}\text { Ukázat rozdíly mezi jednotlivými typy, vyjasnit klíčové } \\
\text { dimenze vzniklé typologie. }\end{array}$ \\
\hline 5 & Diskuse & Zapojit nálezy do kontextu existující teorie. \\
\hline
\end{tabular}


Úroveň 1 zůstává do značné míry mimo text samotný. Čtenář nemá přístup k celému datovému materiálu, stejně jako ke způsobu, jakým byl v první fázi kódován. To, co je v textu zjevné, je jednak zřetězení tematických okruhů, které obvykle v zásadě reprezentují kategorie vzniklé v analýze (viz dále), a dále prrítomnost vybraných datových segmentů. Tím se dostáváme k zásadě, kterou můžeme vytyčit jako závaznou, totiž že v textu musí být vždy př́ítomny fragmenty surových dat. $V$ prrípadě, že metodou sběru dat byly rozhovory, budou tyto fragmenty představovat části přepisů těchto rozhovorů, $\mathrm{v}$ případě, že metodou sběru dat bylo pozorování, budou tyto fragmenty představovat části terénních poznámek pozorovatele atd. Tyto datové úryvky musí být jednoznačně odlišitelné od autorského textu (uvozovkami, jiným typem písma, jiný řádkováním či odsazením). Úryvky z dat je třeba doprovodit kontextuálními informacemi - např́íklad o tom, kdo je původcem dané promluvy, co přecházelo zachycené situaci atd. Kontextualizace je pro čtenáře nutná, aby dokázal posoudit adekvátnost intepretací, které autor nabízí (viz dále úroveň 3).

Úroveň 2 znamená deklarovat, o čem datové úryvky svědčí, formulovat tzv. jádrová tvrzení, tedy jednoduše vyjádřit základní nálezy, k nimž nás naše data vedou. Tyto nálezy formulujeme na základě datové evidence, to znamená, že úroveň 2 je do sebe zaklíněna s úrovní 1 . Vybíráme právě takové datové úryvky, které dosvědčují základní vzorce či pravidelnosti, jichž jsme si v našem materiálu povšimli. A naopak, jádrová tvrzení, jejichž sumarizace vlastně tvoří naše výsledky, dokládáme daty. Z toho plyne jasné doporučení nevkládat do textu takové datové fragmenty, které jsou nějak atraktivní či zajímavé, avšak nedosvědčují naše jádrová tvrzení. Jádrová tvrzení umist’ujeme před jednotlivé datové úryvky, s nimiž jsou ve spojení, př́ípadně za ně. Dále se tato tvrzení znovu vyskytují v souhrnných pasážích - například ve shrnutích na konci kapitol či v závěru.

Práce $\mathrm{s}$ datovými úryvky by se však v textu neměla omezovat na jádrová tvrzení. Tím se dostáváme k úrovni 3, tedy k interpretaci. Autoři mívají mnohdy tendenci interpretaci podceňovat, nebot' se domnívají, že to, co oni sami vidí v datech, je zjevné pro všechny čtenáře. Vyvozování závěrů z dat však není nic přímočarého a samozřejmého. Týž datový úsek mohou různí lidé „přečíst" velmi různým způsobem. ${ }^{9}$ Úkolem výzkumníka je ukázat data

9 Pokud autor vkládá do svého textu datové fragmenty bez vlastních interpretací, de facto po čtenáři požaduje, aby provedl vlastní analýzu těchto fragmentů, a to bez toho, že by měl k dispozici celý datový materiál. 
(úroveň 1) a následně osvětlit, jaký význam jim připisuje. Interpretace, kterou autor obvykle umist'uje bezprostředně za daný datový fragment, je tedy aktem hledání významu daného výroku či akce. Nestačí konstatovat, že to, co ř́kají naši respondenti, je zajímavé, ani jednoduše vlastními slovy opakovat či variovat datový úryvek. Cílem interpretace je udělat určitý myšlenkový skok. Víme, že se něco děje (úroveň 2) a je třeba nabídnout vysvětlení, proč se to děje (úroveň 3). Můžeme tedy formulovat doporučení, aby ke každému úryvku $\mathrm{z}$ dat byla připojena rozpracovaná intepretace. Pokud nejsme $\mathrm{s}$ to úryvek uspokojivě interpretovat, nemá v našem textu co dělat.

Existují určitá nebezpečí, jimž na úrovni 3 musíme čelit. Vždy se musíme soustředit na svoji výzkumnou otázku, která obvykle pomáhá zaostřit výzkum tak, aby poskytl výsledky v souladu se stanovenými cíli, a ukazuje také cestu, jak výzkum vést. Jde tedy o to interpretovat, proč naši respondenti ř́kají to, co říkají, či dělají to, co dělají, nikoli o hodnocení správnosti jejich výroků či počínání. Podobně nepřípadně bývají namísto interpretací v některých textech rozvíjeny úvahy o tom, jaká politická či jiná opatření by se měla přijmout pro zlepšení situace, kterou respondenti prožívají.

Dalším nebezpečím, kterému je třeba se vyhnout, je tzv. nad-interpretování, tedy tendence tvrdit něco, co $\mathrm{z}$ našich dat nelze př́mo vyvodit. $\mathrm{K}$ nadinterpretování dochází ve chvíli, kdy do citace projektujeme vlastní nepodložené představy o dané situaci. A konečně může být neadekvátní interpretace způsobena tím, že důsledně nehlídáme status našich dat, tedy to, o čem mohou vypovídat.

Následující úryvek z výzkumné zprávy pochází z výzkumu Šedové (2009) zaměřeného na vztahy mezi rodinou a školou na prvním stupni ZŠ. Cílem bylo prozkoumat tyto vztahy v jejich „ideální" podobě. Respondenty výzkumu se proto stali na jedné straně učitelky a na druhé straně rodiče, které tyto učitelky označily jako aktivní a spolupracující. Ve všech případech šlo o rodiče ze střední třídy. Metodou sběru dat se staly individuální rozhovory s učitelkami a párové rozhovory s manželskými dvojicemi.

\section{PŘíKLAD Z VÝZKUMNÉ ZPRÁVY 8}

Rodiče ve sledovaném vzorku téměř unisono vyjadřují spokojenost $\mathrm{s}$ učitelkami svých dětí. To mě zpočátku překvapovalo, nebot' jsem předpokládala, že vzdělaní a sebevědomí středostavovští rodiče se budou alespoň $\mathrm{k}$ některým učitelským praktikám vyjadřovat kriticky a že se ve vzorku objeví také oblíbené a neoblíbené učitelky. Zdá se však, jako by spokojenost nevycházela z vlastností učitelek jako 
spíše z vlastností rodičů. [...] Paní Vránová, která je zkušenou matkou - její tři děti v součtu vystřídaly několik učitelek - k tomu podotýká: Takže my fakt jako mám pocit, že jsme měli zatím štěstí na tu skladbu těch učitelů a na tu komunikaci s nima, jo, že někteří rodiče, vím, co majíjiné učitele, tak že to není úplně, že by si vyskakovali. Z citace vysvítá, že porovnává nejen „své“ a „cizí“ učitelky (které ovšem osobně nezná), ale také sebe a jiné rodiče. $V$ prvním plánu jde o předpoklad, že ke kvalitní komunikaci je zapotřebí dvou stran a neschopnost vyjít s učitelkou je do jisté míry také vinou rodičů. $V$ druhém plánu se patrně skrývá axiom, že dítě dobrého rodiče nemůže mít špatnou učitelku. Pokud by totiž rodič označil učitelku za špatnou, bylo by jeho morální povinností ve vztahu k dítěti situaci nějak řešit, např́klad přeřazením dítěte do jiné třídy či školy. [...] Vyjadřování spokojenosti s učitelkou tak funguje zároveň jako strategie sebepotvrzování v roli dobrého rodiče. (Šed’ová, 2009, s. 45)

Citovaná pasáž je uvozena jádrovým tvrzením o spokojenosti rodičů s učitelkami. Toto tvrzení je výběrově doloženo citací z rozhovoru s paní Vránovou. Citace je dále interpretována, a to se zřetelem $\mathrm{k}$ tomu, o čem data reálně mohou vypovídat. Vzhledem $\mathrm{k}$ tomu, že jde o data od rodičů, vypovídají o rodičích samotných, nikoli o učitelkách. Bylo by proto nekorektní interpretovat tvrzení rodičů, že jejich děti mají dobré učitelky jako důkaz kvality těchto učitelek. Namísto toho jsou výroky o spokojenosti s učitelkami vysvětleny jako součást sebepotvrzování respondentů v roli dobrého rodiče.

Následující prŕíklad je vybrán z nepublikované diplomové práce zaměřené na fenomén rodinného vzdělávání tak, jak jej chápou účastníci vzdělávací akce zaměřené na zvyšování kvality partnerského života Manželská setkání. Tito účastníci se stali respondenty citovaného výzkumu, metodou sběru dat byly individuální polostrukturované rozhovory s nimi.

\section{P̌̌íKLAD Z VÝZKUMNÉ ZPRÁVY 9}

Respondenti [...] si myslí, že o vzdělávacích kurzech tohoto typu je mezi lidmi malé povědomí, informovanost je nedostatečná a propagace malá. To tvrdí například Pavla, která si mimo jiné myslí, že lidé například nemají možnost poslechnout si zkušenosti těch, kteří vzdělávacími kurzy prošli a co jim to dalo do života. Pavla popisuje svůj zážitek, jak na ni zapůsobilo, když na kurzu viděla ostatní páry, vyslechla si jejich životní př́běhy a mohla sledovat, jak se k sobě chovají. Uvědomila si, jak by její vztah mohl vypadat: „Mě se to dotklo tak, že mi přišlo hodně líto, co bych jakoby mohla prožívat a co neprožívat, jak by to mohlo být krásný a vůbec se mě to dotklo. Hlavně to pro mě bylo něco, jako když ukážeš někomu lízátko a pak mu řekneš, že mu ho nedáś." Z této výpovědi je vidět, že informovanost a sdílení zkušeností lidí, kteří již takové kurzy absolvovali, by mohla být velmi užitečná 
v tom, aby se lidé o vzdělávací aktivity tohoto typu začali více zajímat. Takový druh osvěty u nás přitom téměř neexistuje. Souhlasím s tím, že o vzdělávacích programech tohoto typu se veřejně velmi málo mluví a vzdělávání týkající se této oblasti se málo propaguje. (nepublikováno)

$\mathrm{Na}$ př́kladu 9 si můžeme ukázat několik interpretačních chyb. Vidíme rozpojení mezi jádrovým tvrzením (Respondenti si myslí, že o vzdělávacích kurzech tohoto typu je mezi lidmi malépovědomí, informovanostjenedostatečná a propagace malá.) a výpovědí Pavly, která hovoří o tom, že si při účasti na kurzu rodinného vzdělávání uvědomila nedostatečnou kvalitu vlastního partnerského vztahu. Je zde př́tomen jistý typ nad-interpretování - autor předpokládá, že pro Pavlu bylo toto uvědomění užitečné, aniž by k tomu byla v datovém úryvku nějaká evidence.

Namísto věcné interpretace datového úryvku se dále konstatuje, že je třeba posílit informovanost potenciálních účastníků o existenci akcí tohoto typu. Toto konstatování má normativní, nikoli explanativní charakter (nepřispívá k objasnění toho, jak účastníci rodinného vzdělávání toto vzdělávání vnímají a prožívají, nýbrž vytyčuje normy pro praktické jednání zainteresovaných aktérů) a navíc nijak nevyplývá z dat, která zde autor textu prezentuje.

Úroveň 4 zahrnuje komparaci případů v našem vzorku. Pokud existují zjevné variace $\mathrm{v}$ některých ze sledovaných kategorií, může komparace vést $\mathrm{k}$ vytvoření typologie. Komparaci přitom $\mathrm{v}$ analýze provádíme vždy (konstantní komparace je ostatně jedním z klíčových principů kvalitativní analýzy - viz Glaser, 2004), ale pokud nezaznamenáme významnou variabilitu, nemá smysl konstruovat typologii.

Dobrá typologie je vždy systematická a musí mít robustní konstrukci. ${ }^{10}$ To znamená, že nejde jen o sadu impresionistických nálepek, jimiž označíme určité skupiny našich př́ípadů. Jde o způsob třídění případů podle několika dimenzí, jejichž naplnění systematicky sledujeme. Tyto dimenze musí být vybrány tak, aby reprezentovaly klíčové charakteristiky zkoumaného jevu. (S trochou nadsázky můžeme říci, že nemá cenu typologizovat učitele

10 Kvalitativní výzkum pracuje sice v prvé řadě s textem, ale schémata či tabulky identifikující nalezené faktory či proměnné mohou čtenáři naznačit komplexnost popisovaného jevu a souvztažnost mezi různými jeho aspekty či dimenzemi. Za návodné a přispívající k pochopení problému považujeme proto texty Rendla (1994), Šed'ové a Zounka (2007), Sedláčka (2008), Pietarinena a Meriläinena (2008), Krutilové (2009), kteří tyto vizuální prostředky užívají s ohledem na čtenáře. 
podle barvy očí či vlasů.) Při psaní tudíž musíme postupovat tak, abychom čtenářum ukázali konstrukci typologie - klíčové dimenze, z nichž je typologie vystavěna, a vyjasnili naši definici těchto dimenzí.

Při prezentování typologie $\mathrm{v}$ textu bychom čtenářům měli nabídnout př́ípadovou ilustraci každého jednotlivého typu (prostřednictvím citování úryvků z dat - zde se vracíme na úroveň 1 ). Zároveň ale stále musíme mít na zřeteli všechny př́ípady ve vzorku. Pokud je naše typologie dobrá, každý typ by měl být v našem datovém materiálu zastoupen několika př́pady (typ, pod který spadne jeden případ, je na pováženou) a zároveň by žádný z případů, které jsme sledovali, neměl zůstat bezdůvodně mimo typologii jako nezařaditelný. Může se stát, že některé př́ípady nezapadnou jednoznačně do jediného typu a zůstanou „na pomezí", avšak pokud se takto chová většina př́ípadů, není konstrukce naší typologie $\mathrm{v}$ pořádku a neposlouží nám jako účinný explanační nástroj. Funkčnost navržené typologie ověříme tak, že všechny naše př́ipady (respondenty, pozorované hodiny apod.) roztřídíme do jednotlivých typů - tím zjistíme, zda jednotlivé typy zastupují dostatečné množství př́ípadů a do jaké míry jsou vzájemně výlučné či propustné a zda vůbec dokáží absorbovat naše př́pady. ${ }^{11}$

\section{PříKLAD z VÝZKUMNÉ ZPRÁVY 10}

Rabušicová, Kamanová a Pevná (2012) ve svém textu o mezigeneračním učení $\mathrm{v}$ rodinách nabízejí rozpracovanou typologii rodinných edukátorů, jež klade za cíl postihnout role, do nichž se dostávají různí rodinní př́íslušníci v procesech mezigeneračního učení. Autorky načrtávají typologické schéma, v němž klíčové dimenze tvoří (1) aktivita/pasivita edukátorů; (2) orientace na potřeby př́jemce / zkušenosti edukátora. Kombinací těchto dvou dimenzí se vytváŕí čtyři pole, z nichž každé obsazuje jeden typ rodinného edukátora: (A) konzultant (pasivní, orientace na potřeby); (B) rádce (aktivní, orientace na potřeby); (C) expert (aktivní, orientace na zkušenosti); (D) vzor (pasivní, orientace na zkušenosti).

$\mathrm{Na}$ „Žebříku“ postupného abstrahování tvoří poslední příčku úroveň 5, tedy teoretická generalizace. Zde je třeba vyjasnit, o jaký typ generalizace jde. Hammersley (1992, s. 45) rozlišujemezi empirickoua teoretickou generalizací. Zatímco empirická generalizace znamená úvahu o přenositelnosti získaných nálezů za hranice studovaného vzorku, teoretickou generalizací míníme aplikaci nově vyvinutých konstruktů do širšího teoretického kontextu dané

11 Ty př́ípady, které vzniklá typologie absorbovat nedokáže, bychom měli podrobit analýze deviantních případů (viz Silverman, 2005, s. 193). 
disciplíny. Jako taková je teoretická generalizace součástí analýzy dat, nebot' v jejím rámci kulminuje výstavba nové teorie.

Mezi základní rysy kvalitativního výzkumu patří jeho potenciál budovat novou teorii induktivně z dat (Strauss \& Corbinová, 1999). Budování teorie se může zastavit na úrovni 4. To znamená, že jsou formulována jádrová tvrzení, doložena datovým materiálem a interpretována. $V$ optimálním případě však dojde v samotném závěru k „abstraktnímu zdvihu“, a to ve dvou rovinách: (a) dojde k částečné dekontextualizaci nálezů, které následně vypovídají o obecnějších procesech, než byly původně studovány; (b) nově vzniklé koncepty jsou napojeny na jiné koncepty, které již byly v dané disciplíně vyvinuty, a existuje o nich určitá evidence. Ve výsledku tak naše nálezy rozvíjejí již ustavené teorie a zaplňují jejich bílá místa, stejně tak ovšem mohou redefinovat ustavené koncepty nebo negovat nálezy dosud přijímané jako platné. Pro kvalitní studii realizovanou na bázi kvalitativního výzkumného přístupu proto platí pravidlo diskutovat nově získané nálezy v širším teoretickém kontextu mateřské disciplíny. Autor v této fázi psaní musí proplout mezi Skyllou ignorance nakumulovaného poznání a Charybdou prostého opakování již známého. Cílem teoretické generalizace je vždy rozšíření interpretačního pole uvnitř dané disciplíny, a to jak ve směru dovnitř do textu („vypůjčujeme“ si teze a koncepty jiných autorů a užíváme je při interpretaci vlastních nálezů), tak ve směru ven $\mathrm{z}$ textu (naše nálezy mohou umožnit reinterpretace nálezů či tezí jiných autorů).

\section{PříKLAD Z VÝZKUMNÉ ZPRÁVY 11}

Lojdová (2013) realizovala výzkum zaměřený na procesy učení v subkulturách. Vybrala si dvě různé subkultury (skinheads a freegans), s jejich členy prováděla hloubkové rozhovory a pozorovala jejich aktivity. Na základě získaných dat popsala nejen to, jak se členové subkultur učí vzájemně jeden od druhého, ale především to, jak se obracejí $\mathrm{k}$ širší veřejnosti s cílem předat informace a změnit postoje a chování ne-členů vlastní subkultury. Povahu tohoto jednání následně interpretovala za pomocí konceptů kritické pedagogiky a veřejné pedagogiky, které jsou $\mathrm{v}$ zahraničí rozpracovávány, avšak nejsou vztahovány přímo k subkulturám. Toto konceptuální napojení jednak posílilo schopnost autorky uvažovat o sledovaných jevech z pedagogického hlediska, jednak v důsledku vedlo k vytvoření inovativního konceptu tzv. neoficiálních vzdělávacích agentů. 


\section{Jazyk a psaní výzkumné studie}

Ačkoli je celý tento text věnován otázce, jak napsat dobrý kvalitativní článek, předcházející kapitoly se vztahovaly $\mathrm{k}$ procesům, které probíhají dávno předtím, než autor zasedne ke stolu, aby napsal první řádky svého budoucího textu. $\mathrm{V}$ tomto oddíle se budeme zabývat problémy, které je třeba řešit v průběhu samotného psaní.

V prvé řadě je třeba ujasnit si, o jaký typ článku půjde. Komplexnější kvalitativní výzkum obvykle nabude rozměrů, které nejsou vměstnatelné do formátu článku v časopise. (Připomeňme na tomto místě jedno banální, avšak důležité pravidlo, totiž že by se měl autor řídit požadavky na délku textu, které ten který časopis deklaruje jako závazné.) Proto při publikaci výstupů z kvalitativního šetření vždy vybíráme, jakou část našich výsledků budeme čtenářům prezentovat.

Klíčové rozhodnutí, které musí autor při psaní udělat, se týká struktury textu. Silverman (2005, s. 253-261) rozlišuje mezi makrostrukturou a mikrostrukturou. Zabývat se makrostrukturou znamená rozčlenit text na kapitoly tak, aby tvořily logický a důvěryhodný celek. Na tomto místě se nebudeme zabývat obecně strukturou celé výzkumné studie, nýbrž jen uspořádáním části týkající se získaných dat a jejich analýzy. ${ }^{12}$ Prezentace nálezů z kvalitativního výzkumu se liší od prezentace nálezů z výzkumu kvantitativního. Kvantitativní studie jsou obvykle organizovány v logice hypotéz. Autor předloží svoji hypotézu, ukáže postup při jejím ověřování, konstatuje verifikaci či falzifikaci hypotézy a diskutuje své závěry. Kvalitativní studie takovouto kanonizovanou strukturu nemají. To dává autorům na jedné straně větší volnost a umožňuje jim to tvořivější přístup k psaní. Na druhé straně fakt, že nejsou vedeni relativně úzkým koridorem hypotézy, může vést $\mathrm{k}$ jistému „ztrácení se" v množství dat a nálezů. Autorům chybí jasné vodítko, jak článek uspořádat, čtenářům potom jasné vodítko, jak článek číst.

V metodologické literatuře se zmiňuje několik způsobů, jak prezentaci výzkumu strukturovat. Patrně nejběžnější je strukturace textu podle klíčových témat, př́ípadně podle klíčových nálezů (srov. Rubin \& Rubin, 2005, s. 221). Budeme-li se držet tematického uspořádání, můžeme využít výstup z kódování a kategorizace dat (viz výše), totiž seznam kategorií, do nichž jsme data

12 Obecnou strukturou typu úvod - dosavadní poznatky o tématu - metodologie - prezentace dat a nálezů - diskuse - závěr provádí řada metodologických učebnic - viz např. Novotný (2007). 
roztřridili. Jednotlivé kategorie budou odpovídat kapitolám či subkapitolám ve vznikajícím textu. Budeme-li text strukturovat podle nálezů, budou naše kapitoly odpovídat nejdůležitějším jádrovým sdělením (viz výše). Rizikem organizace podle kategorií či jádrových nálezů může být nedostatečná centralizace směrem k ústředním jevům. Není žádoucí prezentovat všechny kategorie, do nichž jsme naše data roztř́ídili, ani všechny teze, která naše data dosvědčují. Text je potom prŕliš popisný a rozostřený. Je třeba zvolit centrální body - vzhledem k výzkumné otázce - „nadbytečné“ části na ně napojit, nebo jednoduše vypustit.

\section{PŘíKLAD Z VÝZKUMNÉ ZPRÁVY 12}

Jako př́klad strukturace textu podle vzniklých kategorií můžeme uvést článek Filagové (2010), který se zabývá socializačními efekty specifické organizace času v mateřské škole. Jednotlivé kapitoly (názvy uvádíme dále kurzívou) odpovídají různým kategoriím časových fenoménů, které výzkumnice ve zkoumaném prostředí pozorovala: (1) Režim dňa alebo "Čo budeme potom?" - segmentace aktivit podle pravidelného časového schématu školního dne; (2) Kalendárový život spoločnosti alebo „Dnesje pyžamkový deň“ - časová výlučnost některých dní vázaná na kalendářní členění roku, měsíce a týdne; (3) Záväznost' časového rámca alebo „Pohyb, pohyb, decká!" - disciplinace dětí do předdefinovaných časových rámců; (4) Prerušenia a upriamovanie pozornosti - socializace do školního pravidla věnovat se v jednom okamžiku pouze jedné činnosti; (5) Biologický čas alebo Maláci a vel'káci - konstruování identitních rozdílů mezi dětmi na pozadí jejich př́íslušnosti k určité věkové skupině; (6) Zvonenie - předěl mezi různými činnostmi.

\section{PŘíKLAD z VÝZKUMNÉ ZPRÁVY 13}

Jako př́klad strukturace textu podle jádrových sdělení můžeme uvést článek Bradové (2012) věnovaný otázce fungování zasedacího pořádku. Jednotlivé kapitoly (názvy uvádíme dále kurzívou) uvozují jádrová sdělení v nich obsažená: (1) Učitelsko-žiacke preferencie v obsadzovaní riestoru triedy - žáci preferují určitá místa, kde by chtěli ve třídě sedět, učitelé těmto preferencím bud’ vychází vstříc, nebo jim kladou odpor; (2) Štádia dimenzácie žiackeho priestoru - existují jasně odlišitelná časová stádia, jimiž zasedací pořádek v průběhu školního prochází; (3) Ked' zasadací poriadok funguje - existuje rovnovážný bod, v němž jsou učitelé i žáci se zasedacím pořádkem spokojeni a považují jej za nástroj naplňování vlastních cílů.

Existují však i další způsoby, jak kvalitativní výzkumnou studii strukturovat. White, Woodfield a Ritchie (2003, s. 295) uvádějí například uspořádání podle výzkumného postupu nebo uspořádání podle existující teorie. Uspořádání podle výzkumného postupu znamená sledovat logiku našeho výzkumného 
designu - prezentujeme například odděleně různé skupiny případů nebo data získaná v různých fázích výzkumu.

\section{PříKLAD z VÝZKUMNÉ ZPRÁVY 14}

Logiku výzkumného designu kopíruje uspořádání kapitol ve dvou na sebe navazujících článcích M. Pola et al. $(2009,2010)$. Články představují výstup z biografického výzkumu zaměřeného na vývoj profesní identity ředitelů českých základních škol, základní metodou sběru dat se staly opakované rozhovory $\mathrm{s}$ řediteli zachycující jejich životní a profesní historii. Jednotlivé kapitoly jsou sestaveny podle fází, jimiž ředitelé postupně procházejí. Skutečnost, že lze dráhu ředitelů rozložit do fází, byla přitom a priori předpokládána a byl jí podřízen plán rozhovorů. Záměr určit jednotlivé relevantní fáze je plně v souladu s povahou biografického designu. Články zahrnují následující kapitoly: (1) Předehra - aneb Jak se člověk stane ředitelem školy?; (2) Fáze první - vstup do ředitelny; (3) Fáze druhá - čas osobních zkoušek; (4) Fáze profesní jistoty; (5) Druhé přechodové období - čas zesílené reflexe chodu školy?; (6) Fáze nových výzev - zkušený ředitel.

Uspořádání textu podle výzkumného plánu nebo podle teorie je lákavé, nebot’ nabízí předem připravenou strukturu, kterou není třeba vynalézat. Může ovšem vést $\mathrm{k}$ tzv. „zavěšování" - naše data jsou zavěšena na předem připravené konstrukty či teze. Slouží potom spíše jako ilustrace těchto převzatých východisek, než že by docházelo k budování nového poznání. (Jestliže jsou takto organizovány kvantitativní studie, je to $\mathrm{v}$ pořádku, nebot' ty umožňují ověřit platnost dané teorie. Kvalitativní výzkum ovšem nic takového neumožňuje.)

Jestliže máme plán makrostruktury - tedy osnovu, seznam budoucích kapitol - musíme se dále zabývat mikrostrukturou, tedy organizací textu v rámci jednotlivých kapitol. Zde platí pravidlo ujasnit si, jaké bude základní sdělení té které kapitoly. Silverman (2005, s. 295) formuluje zásadu vypovídat $\mathrm{v}$ jednom okamžiku pouze o jednom tématu. Jakmile text začne odbíhat jiným směrem, daný materiál má být vypuštěn a použit v jiné části. Tím se znovu dostáváme k otázce cirkularity a linearity. Ačkoli reálně spolu všechny naše nálezy souvisí, tvoří jakási klubka poznatků, v textu tato klubka musíme rozplést a narovnat tak, aby čtenář ve chvíli, kdy čte určitou pasáž, nepostrádal informace, které se v textu objeví teprve později, a na druhé straně, aby se tytéž informace neproduktivně neopakovaly na různých místech. Zřetel k lineární textové posloupnosti (bez informačních mezer, zbytečných redundancí a „rozpíjení“ jednoho tématu do různých částí textu) lze chápat jako další z pravidel kvalitativního psaní. 
V samotném závěru tohoto př́íspěvku se musíme zabývat jazykem. Má se za to, že kvalitativní výzkum je více „literární“ než výzkum kvantitativní. Proto dovednost psát - nejen jasně a přesně, ale též působivě a elegantně patří k výbavě kvalitativních výzkumníků.

Kvalitativní studie mají oproti jiným odborným textům jedno významné specifikum, a tím je př́tomnost jazyka terénu. Úryvky z dat, které jsou do výzkumných zpráv vkládány, jsou velmi vzdálené od akademické jazykové normy - je to řeč nespisovná, zahrnující slangové či vulgární výrazy, parazitní slova, neúplné nebo naopak opakující se větné konstrukce. To vzbuzuje otázku, nakolik datové úryvky upravovat. Ačkoli na tuto otázku neexistuje jednoznačná odpověd, kloníme se k závěru, že spíše minimálně, a to pouze $\mathrm{s}$ cílem přispět k lepšímu porozumění. Můžeme vypustit sekvenci parazitních slov či zvuků, které nenesou žádný význam, není však žádoucí upravovat koncovky slov či nahrazovat užitá slova jinými výrazy. Důsledným grafickým odlišením dáváme jasně najevo, kde začíná a končí řeč našich respondentů a kde promlouvá sám autor. Pokud bychom určitý úsek prezentovali jako přímou řeč a zároveň jej upravovali, uváděli bychom čtenáře v klam.

Rovněž autorský jazyk má ovšem v kvalitativním výzkumu své zvláštnosti. ${ }^{13}$ Jak bylo konstatováno výše, kvalitativní výzkumníci tíhou k určité literárnosti (jejich texty místy připomínají beletrii). Nabízí se otázka, proč tomu tak je, nejde totiž o žádné normativní pravidlo kvalitativního psaní. Napadá nás dvojí vysvětlení: bud' může jít jednoduše o jistý typ módy, který se mezi kvalitativními autory ustavil, nebo jsou k literárnosti „naváděni“ typem dat, který zpracovávají. Podle Brunera (1986, s. 11) existují dva základní typy myšlení: (1) myšlení paradigmatické, jež zahrnuje operace, jako jsou klasifikování, kategorizování, uspořádávání do konceptů a modelů; (2) myšlení narativní, popisující minulé zkušenosti jako řetězce kauzálně propojených akcí. Paradigmatické myšlení je základem moderní vědy a jako takové je též charakteristické pro kvantitativní výzkumné přístupy v sociálních vědách. Narativní myšlení je charakteristické pro literaturu, stejně jako pro běžné lidské přemýšlení o každodenní realitě, nebot' umožňuje pochopit smysl lidského jednání (Bruner, 1986, s. 11). V kvalitativním výzkumu se pracuje především s narativními daty (získanými prostřednictvím rozhovorů či záznamů inter-

13 Velmi často se v různých př́ručkách o psaní vědeckých textů diskutuje o tom, zda-li je možné psát v první osobě jednotného čísla, nebo zda je nutné užít autorský plurál, i když text píše jeden autor. Anglicky psaný článek by měl být psán v první osobě jednotného čísla. Autor česky psaného textu má na výběr z obou možností. 
akce mezi různými aktéry), a tudíž mohou mít výzkumníci tendenci kopírovat logiku těchto dat a vlastní výstupy strukturovat narativně, tedy literárně. Přítomnost narativního myšlení v kvalitativním výzkumu je ostatně v souladu s jeho orientací na zkoumání toho, jak lidé prožívají, chápou a interpretují sociální realitu (srov. Bruner výše).

Kvalitativně orientovaní autoři navíc usilují o vytvoření nové vlastní teorie. $\mathrm{Z}$ tohoto důvodu jim mnohdy „nestačí existující termíny a koncepty a mají tendenci vyvíjet nové pojmy, jimiž se snaží co nejpřesněji vyjádřit svá induktivně vzniklá zjištění. Jedním z běžných způsobů vytváření nových pojmů jsou lexikální postupy přenášení významu (metafora, metonymie) či řečnické figury (hyperbola, eufemismus). Také užití těchto prostředků posiluje literární charakter kvalitativních výzkumných studií.

Literární styl kvalitativních výzkumů můžeme ilustrovat na citaci z článku Brücknerové (2011), který je věnován problematice hodnocení v hodinách výtvarné výchovy. Autorka užívá řadu metafor s cílem představit své induktivně vzniklé koncepty. Termínem kompas např́klad postihuje náklonnost učitelů k začleňování určitých typů témat či úkolů do výuky.

\section{PříKLAD z VÝZKUMNÉ ZPRÁVY 15}

Za hodno pozornosti považuji $v$ tuto chvíli zejména to, na jakém základě tyto učitelské kompasy fungují, co řídí jejich střelky. Již nastíněná komplikovanost a skrytost procesu napovídá, že jakékoli zobecňování je na pováženou, avšak na výpovědích učitelů je přece jen nápadná rozdílnost v přístupu, kterou bychom, v jejích krajních pólech, mohli nazvat důraz na osobní blízkost a důraz na reprezentativnost. Kompasy učitelů, jež kladou důraz na osobní blízkost, se ř́íí většinou pouze osobním vkusem, jsou založeny na intuitivním rozlišování a často preferují díla a úkoly, jež vzbuzují pocity př́ijemné a pozitivní, vysoko je ceněna kvalita označovaná jako zajímavost.

Za tyto učitele si můžeme poslechnout Ivanu, když hovoří o klíči, podle nějž vybírá učivo z dějin umění: „Takže určitě podle toho, co já mám ráda, tak to dělám i s těma děckama, jo. Já nevím, třeba dělávám s devátákama Saudka, protože se mně líbí. S osmákama dělám Gogha, protože se mi líbí. Takže to si myslím, že jednoznačně člověk dělá to, co sám má nejradši, těžko budu dělat Dalího, ke kterýmu nemám vztah a kterej jakoby $v$ těch jeho věcech mi není blízkej." Učitelé s podobným kompasem vybírají z bonboniéry potenciálního kurikula to, co jim samotným chutná, a tento výběr pak předávají žákům v dobré víře, že totéž bude chutnat i jim, anebo dokonce s přesvědčením, že vybrali na základě své erudice to nejlepší. (Brücknerová, 2011, s. 52-53) 
V citaci vidíme, že autorka užívá nepedagogický pojem kompas zcela samozřejmě (bez uvozovek, s běžnou flexí), jako by šlo o ustavený oborový termín. Porozumění čtenářủ si zajišttuje explicitním vyložením významu slova v předcházejícím textu, kde kompas definuje jako „soubor hodnoticích situací, kterými učitel prosívá své dosavadní poznání a zkušenosti a na jejich základě (často dosti intuitivně) vytváří obsah, který se rozhoduje žákům nabízet" (Brücknerová, 2011, s. 52). Jde o metaforické přenesení významu - kompas je něco, na základě čeho řídíme svoji cestu. Všimněme si, že nejde o jediný nestandardní lexikální prvek v citovaném úryvku, dále autorka ve svém komentáři přirovnává kurikulum $\mathrm{k}$ bonboniéré, z níž si učitelé vybírají, co jim chutná. Tyto metafory nemají pouze hodnotu estetickou, nýbrž i explanační. Umožňují autorce přesvědčivě vykreslit různé typy učitelů. Dále totiž popisuje učitele, kteří si z bonboniéry berou povinně od každého druhu - ti se řídí svou představou o závazných a závažných obsazích, které je žákům třeba zprostředkovat.

Výše uvedená jazyková specifika mohou kvalitativní texty estetizovat a ozvláštňovat, činí je čtenářsky atraktivnějšími. Skrývají však také určitá nebezpečí, jimž je třeba se vyhnout.

Především se vpádem pojmů, které nejsou odborné (jazyk terénu) či ustavené (inovativní autorské termíny) rozrušuje jednoznačnost a spolehlivost vědeckého jazyka. Použije-li metaforu básník, dociluje tím nejednoznačnosti a možné mnohovýznamovosti svého sdělení. Tím se posiluje estetický účinek a interpretační prožitek čtenáře. Ve vědeckém textu jsou však takové efekty jednoznačně na škodu, nebot' odborné sdělení má být $v$ prvé řadě jasné a přesné. Proto je v kvalitativním výzkumu nezbytné permanentní definování užívaných pojmů. Co se týče autorského jazyka, jsou implikace jasné: každý nově zavedený termín musí být precizně vysvětlen a definován.

Poněkud složitější situace nastává tam, kde pracujeme s jazykem terénu. Zde totiž narážíme na pocit jakési shody v chápání pojmů mezi výzkumníkem, respondentem a čtenářem, který ovšem může být iluzorní. Plasticky tento jev popisuje ve své metodologické studii Švaříček (2010, s. 155) - jestliže výzkumníkovi například učitel v rozhovoru sdělí, že jeho prvořadým cílem je mít „dobrý vztah se žáky“, není možné tuto informaci jednoduše citovat a vytvořit z ní jádrové sdělení. Zcela klíčové je totiž zjistit, co přesně podle respondenta dobrý vztah znamená (je k nim spravedlivý, nebo mírný v hodnocení; chce je přimět k zájmu o svůj předmět, a tím i k soustředěné 
práci, nebo se je naopak snaží nestresovat přehnanými požadavky; má je rád nebo dělá vše pro to, aby oni měli rádi jeho?). Termínu „dobrý vztah“ rozumí každý, avšak každý mu přičítá různý význam. Bez jasného určení obsahu tohoto pojmu nemá smysl s ním operovat v odborném textu.

\section{PříKLAD z VÝZKUMNÉ ZPRÁVY 16}

Jako př́klad na obezřetnou práci s jazykem respondentů můžeme uvést ukázku z článku Nedbálkové (2012), který je věnován tř́ídnímu vědomí dělníků. Autorka cituje názor stavebního dělníka Zdeňka na aktuálně probíhající stávku ve veřejné dopravě:

R: Co si o tom myslím? No, že asi nic nedokážou, ale podporuju je, protože taky se mi nelíbí, co tahle vláda tady na tu naši vrstvu chystá, protože je to hrozný, je to neúnosný, už si myslím.

T: Naši vrstvu, co myslíte tím ...

R: ... vás, mě, třicátníci, čtyřicátníci. (Nedbálková, 2012, s. 92)

Ačkoli by se $\mathrm{v}$ sociologické terminologii nabízelo ztotožnit termín vrstva se socioekonomickou třídou, ke které respondent náleží, tazatelka díky důslednému zjištování obsahů užívaných slov může výrok interpretovat jinak, totiž jako vázaný na př́íslušnost $\mathrm{k}$ jisté věkové kategorii.

V závěru kvalitativně orientované studie by mělo dojít ke shrnutí empirických zjištění a ke spojení našeho výzkumu s teoretickým rámcem ve formě pomyslného dialogu mezi autorem a citovanými odborníky na dané téma.

\section{Závěr}

Ústřední otázkou našeho textu bylo formulovat doporučení pro autory píšící kvalitativně orientované výzkumné studie. Postupně jsme uvedli celkem 16 pravidel, která sumarizujeme v tabulce 2 spolu s odkazem na příslušnou část textu, $\mathrm{v}$ níž je třeba to které pravidlo sledovat. Zároveň $\mathrm{v}$ tabulce uvádíme typická nebezpečí, jimž v různých fázích psaní musíme čelit. Tato nebezpečí jsou vlastně odvrácenou stranou formulovaných pravidel - stávají se reálnými ve chvíli, kdy se nám nepodaří jednotlivá pravidla adekvátním způsobem dodržet. 


\section{Tabulka 2}

\section{Pravidla kvalitativního psaní}

\begin{tabular}{|c|c|c|}
\hline Část článku & Pravidlo & Nebezpečí \\
\hline Abstrakt & Zaujmout čtenáře & $\begin{array}{l}\text { Čtenář není přesvědčen } \\
\text { o významnosti či zajímavosti } \\
\text { předkládané studie a text odloží }\end{array}$ \\
\hline Úvod & Uplést tenkou červenou nit & $\begin{array}{l}\text { Roztř́ištěné zaměření textu } \\
\text { Neujasněné hlavní sdělení }\end{array}$ \\
\hline \multirow[t]{3}{*}{$\begin{array}{l}\text { Teoretický } \\
\text { rámec }\end{array}$} & $\begin{array}{l}\text { Užívat primární zdroje s vlastním } \\
\text { komentářem }\end{array}$ & Nedůvěryhodné vysvětlení \\
\hline & $\begin{array}{l}\text { Tvưrčím způsobem vysvětlit } \\
\text { teoretické koncepty }\end{array}$ & Nespolehlivé sdělení \\
\hline & Popsat zámořské i domácí objevy & Neznalost relevantních zdrojů \\
\hline \multirow[t]{3}{*}{ Metodologie } & $\begin{array}{l}\text { Propojit tenkou červenou linii } \\
\text { s teoretickým rámcem a výzkumnými } \\
\text { otázkami }\end{array}$ & $\begin{array}{l}\text { Výzkumný plán není v souladu se } \\
\text { stanoveným cílem }\end{array}$ \\
\hline & $\begin{array}{l}\text { Zdokumentovat průběh cesty } \\
\text { v terénu }\end{array}$ & Čtenář je cizincem v cizí zemi \\
\hline & Představit čtenáři zkoumané jedince & Čtenář si domýšlí analýzu dat \\
\hline \multirow[t]{5}{*}{ Výsledky } & $\begin{array}{l}\text { Dobře ošetřit datové fragmenty } \\
\text { v textu }\end{array}$ & $\begin{array}{l}\text { Nejasné odlišení dat a autorského } \\
\text { textu } \\
\text { Nedostatečná kontextualizace dat }\end{array}$ \\
\hline & Jasně propojit data a jádrová tvrzení & $\begin{array}{l}\text { Atraktivita jako vůdčí princip při } \\
\text { výběru datových fragmentů }\end{array}$ \\
\hline & Nabídnout rozpracované interpretace & $\begin{array}{l}\text { Hodnoticí přístup } \\
\text { Nad-interpretovávání } \\
\text { Závěry neodpovídající statusu dat }\end{array}$ \\
\hline & $\begin{array}{l}\text { Navrhnout transparentní a funkční } \\
\text { typologie }\end{array}$ & $\begin{array}{l}\text { Typologie bez konstrukce } \\
\text { Typologie bez třídící funkce } \\
\text { Typologie neodpovídající případům }\end{array}$ \\
\hline & $\begin{array}{l}\text { Zapojit nálezy do kontextu existující } \\
\text { teorie }\end{array}$ & $\begin{array}{l}\text { Neznalost relevantních zdrojů } \\
\text { Opakování známého }\end{array}$ \\
\hline \multirow[t]{3}{*}{$\begin{array}{l}\text { Průběžně } \\
\text { v celém textu }\end{array}$} & Logicky rozčlenit kapitoly & $\begin{array}{l}\text { Nedostatečná soustředěnost na } \\
\text { centrální nálezy } \\
\text { Zavěšování }\end{array}$ \\
\hline & Udržovat linearitu textu & $\begin{array}{l}\text { Rozpíjení témat } \\
\text { Mezery a redundance }\end{array}$ \\
\hline & Permanentně definovat pojmy & $\begin{array}{l}\text { Spoléhání na všeobecný sémantický } \\
\text { konsenzus }\end{array}$ \\
\hline
\end{tabular}

Dodržení výše uvedených pravidel považujeme za nezbytné pro úspěšné otištění výzkumné zprávy v odborném recenzovaném časopise. Př́i jejich 
nedodržení se autor vystavuje velkému riziku, že se v recenzním posudku na svůj rukopis dočte věty následujícího typu:

Tématem článku je evaluace a zpětná vazba, ale autoři takřka nedefinují tyto pojmy s použitím konceptů kognitivní psychologie.

Zpětná vazba je velmi komplexním procesem, který je zároveň vázán na specifický kontext a zároveň na osobu učitele, ale popisovaný výzkum selhal v tom, aby zachytil jemné nuance těchto charakteristik.

Článek neukazuje, jak sociální a kulturní kontext zásadním způsobem ovlivňuje zkoumané jevy, které se autoři snaží zachytit empirickým výzkumem v každodenní realitě školní třídy. Autoři hodnotí vyučování učitele ze svého pohledu místo toho, aby se pokusili porozumět, jak jsou zkoumané jevy ukotveny v kontextu.

Při popisu zpětné vazby a evaluace používají autoři velké množství pojmů, které nahlížejí jako jasné a dané místo toho, aby je zproblematizovali a zkoumali poctivým empirickým výzkumem. Mezi tyto „jasné“ pojmy patří - pozitivní, negativní, správné a nesprávné odpovědi, dobrý a špatný výkon žáka, přirozený talent a další.

Autoři se snaží v článku postihnout př́lišs mnoho věcí. Doporučuji se zaměřit pouze na jeden jev - zpětnou vazbu.

Text má čtyřicet osm stran - to je pro náš časopis nepřiměřeně velký rozsah.

Na tomto místě jsme si dovolili být poněkud osobní, nebot' citujeme z posudků, které jsme na jeden z našich textů dostali, když jsme jej nabídli k publikaci v zahraničním časopise. Musíme tedy přiznat, že ačkoli jsme na výzvu redakce Pedagogické orientace sepsat text vyjadřující se k metodologickým standardům kvalitativního psaní odpověděli pozitivně a takovýto text zde nabízíme, rozhodně nejsme sami imunní vůči různým nešvarům a obtížím, které s sebou akademické psaní přináší. ${ }^{14} \mathrm{~V}$ úvodu této studie jsme uvedli, že stanovení kvality kvalitativního odborného článku je vždy věcí konsenzu. V ustavování tohoto konsenzu a obecně v kontrole kvality odborných publikací právě recenzní posudky, které jsou obligatorní součástí „provozu“ vědeckých časopisů, hrají velmi důležitou roli. Ve chvíli, kdy obdržíme recenzní posudek, začíná další kolo práce na textu a přichází nová př́ležitost uvést náš článek do souladu s pravidly kvalitativního psaní. Recenzenti a redaktoři časopisů jsou našimi partnery v tomto úsilí. I náš text byl nakonec publikován (Šed'ová \& Švaříček, 2012), a to ve výrazně vyšší kvalitě, než v jaké jsme jej redakci původně nabízeli.

Jsme v této chvíli vcelku zkušení autoři, a přesto je pro nás každá nová publikace - především v zahraničních časopisech - velmi dobrodružným a nejis-

14 Tento článek je spíše formou autorského sebezpytu než expertní snahy poučovat ostatní. 
tým podnikem. Každý časopis má totiž specifickou redakční kulturu a specifické požadavky na délku textu, způsob jeho strukturace a také na obsahové zaměření. Chceme-li tedy, aby náš článek byl publikován, musíme se důkladně seznámit s časopisem, do kterého text zasíláme. Všechny solidní akademické časopisy uveřejňují na svých webových stránkách pokyny pro autory, vedle toho je samozřejmě výhodou, máme-li s daným časopisem čtenářskou zkušenost, a tudíž také představu, jaký typ textů je zde publikován.

Tím se dostáváme k poslednímu pravidlu, které bychom v tomto článku chtěli nechat zaznít, ačkoli se nám „nevešlo“ do tabulky výše, nebot' je obecnější a netýká se jen kvalitativních studií. Toto pravidlo zní: Abychom mohli dobře psát, musíme $v$ prvé řadě hodně a pozorně číst.

\section{Literatura}

Altheide, D. L., \& Johnson, J. M. (1994). Criteria for assessing interpretive validity in qualitative research. In N. K. Denzin \& Y. S. Lincoln (Eds), Handbook of qualitative research (s. 485499). Thousand Oaks: Sage.

Ball, S. J. (1991). Power, conflict, micropolitics, and all that! In G. Walford (Ed.), Doing educational research (s. 166-192). London: Routledge.

Bochner, A. P. (2000). Criteria against ourselves. Qualitative Inquiry, 6(2), 266-272.

Bradová, J. (2012). Ked' zasadací poriadok funguje alebo Učitel'sko-žiacke preferencie pro obsadzovaní priestoru školskej triedy. Studia paedagogica, 17(2), 71-92.

Bruner, J. (1986). Actual minds, possible worlds. Cambridge: Harward University Press.

Brücknerová, K. (2011). Paleta hodnotících situací a přístupů ve výtvarné výchově. Studia paedagogica, 16(2), 49-74.

Čálek, O. (1995). Zkoušení očima žáků. In Pražská skupina školní etnografie. Typy žáků: zpráva z terénního výzkumu. Praha: Pedagogická fakulta Univerzity Karlovy. Dostupné z http:// userweb.pedf.cuni.cz/kpsp/etnografie/vyzkum/Typy/calek.pdf

Ellis, C. (2000). Creating criteria: An ethnographic short story. Qualitative Inquiry, 6(2), 273-277.

Filagová, M. (2005). Materská škola cez rodové okuliare. Pedagogika, 55(3), 248-263.

Filagová, M. (2010). (Na)časovanie se v materskej škole. Studia paedagogica, 15(1), 47-63.

Flick, U. (2006). An introduction to qualitative research. London: Sage.

Freeman, M., deMarrais, K., Preissle, J., Roulston, K., \& St. Pierre, E. A. (2007). Standards of evidence in qualitative research: An incitement to discourse. Educational Researcher, 36(1), 25-32.

Furman, R., Langer, C. L., Davis, C. S., Gallardo, H. P., \& Kulkarni, S. (2007). Expressive, research and reflective poetry as qualitative inquiry: A study of adolescent identity. Qualitative Research, 7(3), 301-315.

Glaser, B. (1978). Theoretical sensitivity. Advances in methodology of grounded theory. Mill Valey: The Sociology Press. 
Glaser, B. (2004). Remodeling grounded theory. Forum Qualitative Sozialforschung/ Forum: Qualitative Social Research, 5(2), článek 4.

Guba, E. G., \& Lincoln, Y. S. (1981). Effective evaluation: Improving the usefulness of evaluation results through responsive and naturalistic approaches. San Francisco: Jossey-Bass.

Guba, E. G., \& Lincoln, Y. S. (2005). Paradigmatic controversies, contradictions, and emerging confluences. In N. K. Denzin \& Y. S. Lincoln (Eds.), SAGE Handbook of qualitative research (s. 191-215). Thousand Oaks: Sage.

Hammersley, M. (1992). What's wrong with ethnography! London: Routledge.

Hammersley, M. (2007). The issue of quality in qualitative research. International Journal of Research and Method in Education, 30(3), 287-305.

Katrňák, T. (2004). Odsouzeni k manuální práci. Vzdělanostní reprodukce v dělnické rodině. Praha: SLON.

Kitto, S. C., Chesters, J., \& Grbich, C. (2008). Quality in qualitative research. Medical Journal of Australia, 188(4), 243-246.

Krutilová, K. (2009). Metoda soutěžní debaty v české škole. Studia paedagogica, 14(1), 179-188.

Kuhn, T. S. (1997). Struktura vědeckých revolucí. Praha: Oikoymenh.

Kvale, S. (1996). InterViews. An introduction to qualitative research interviewing. Thousand Oaks: SAGE.

Lojdová, K. (2013). Učitelé dobra a zla: Subkultury ve veřejné pedagogice (Dizertační práce). Brno: ÚPV FF MU.

Makovská, Z. (2011). Techniky změny chování a jejich využití ze strany žáků. Pedagogická orientace, 21(1), 85-103.

Miles, M. B., \& Huberman, A., M. (1994). Qualitative data analysis: An expanded sourcebook. London: Sage.

Morse, J. M., Barrett, M., Mayan, M., Olson, K., \& Spiers, J. (2002). Verification strategies for establishing reliability and validity in qualitative research. International Journal of Qualitative Methods, 1(2), článek 2.

Nedbálková, K. (2012). Tak daleko, tak blízko: dělnická třída v České republice. Sociální studia, 9(3), 85-100.

Novotný, P. (2007). Psaní napříč kvalitativním výzkumem. In R. Švaříček \& K. Šed'ová (Eds.), Kvalitativní výzkum v pedagogických vědách. Praha: Portál.

Pietarinen, J., \& Meriläinen, M. (2008). Aktivní a pasivní fáze kariéry učitele v kontextu málotř́ídní školy. Studia paedagogica, 13(1), 65-84.

Pol, M., Hloušková, L., Novotný, P., \& Sedláček, M. (2009). Úvodní fáze profesní dráhy ředitelů základních škol. Studia paedagogica, 14(1), 109-126.

Pol, M., Hloušková, L., Novotný, P., \& Sedláček, M. (2010). Profesní dráha ředitelů základních škol: od fáze profesní jistoty k novým výzvám. Studia paedagogica, 15(1), 85-106.

Průcha, J., \& Švaříček, R. (2009). Etický kodex české pedagogické vědy a výzkumu. Pedagogická orientace, 19(2), 89-105.

Rabušicová, M., Kamanová, L., \& Pevná, K. (2012). Mezigenerační učení: učit se mezi sebou v rodině. Studia paedagogica, 17(1), 163-182.

Rendl, M. (1994). Jak se děti učí. Pedagogika, 44(1), 51-60.

Rolfe, G. (2004). Validity, trustworthiness and rigour: Quality and the idea of qualitative research. Journal of Advanced Nursing, 53(3), 304-310. 
Rubin, H. J., \& Rubin, I. S. (2005). Qualitative interviewing. The art of hearing data. Thousand Oaks: SAGE.

Sedláček, M. (2008). Řízení školy na vesnici. Studia paedagogica, 13(1), 85-99.

Sedláček, M., Pol, M., Hloušková, L., Lazarová, B., \& Novotný, P. (2012). Organizační učení v realitě života školy: impulzy, témata, strategie řízení. Studia paedagogica, 17(2), 27-50.

Seale, C. (1999). The quality of qualitative research. London: SAGE.

Seale, C. (2002). Kvalita kvalitativního výzkumu. Biograf, 27, 3-16.

Shapin, S. (1984). Pump and circumstance: Robert Boyle's literary technology. Social Studies of Science, 14(4), 481-520.

Silverman, D. (2005). Ako robit' kvalitatívny výskum. Bratislava: Ikar.

Smetáčková, I. (2011). Škola jako téma rozhovorů mezi dětmi a rodiči. Studia paedagogica, 16(2), 9-26.

Strauss, A. L., \& Corbinová, J. (1999). Základy kvalitativního výzkumu. Postupy a techniky metody zakotvené teorie. Boskovice: Albert.

Šed'ová, K. (2009). Tiché partnerství: vztahy mezi rodiči a učitelkami na prvním stupni základní školy. Studia paedagogica, 14(1), 27-52.

Šed'ová, K., \& Švaříček, R. (2012). Feedback in dialogical education in Czech secondary schools. Educational Assessment, Evaluation and Accountability, 24(3), 239-261.

Šed'ová, K., \& Zounek, J. (2007). ICT a moc před tabulí. In R. Švaříček \& K. Šed'ová (Eds.), Kvalitativní výzkum v pedagogických vědách. Pravidla hry (s. 260-286). Praha: Portál.

Švaříček, R. (2007). Kritéria kvality kvalitativního výzkumu. In R. Švaříček \& K. Šedová (Eds.), Kvalitativní výzkum v pedagogických vědách. Pravidla hry (s. 28-50). Praha: Portál.

Švaříček, R. (2010). Čas, vzpomínky a řečnické figury v rozhovoru. Studia paedagogica, 15(1), 147-176.

Švaříček, R. (2011). Funkce učitelských otázek ve výukové komunikaci na druhém stupni základní školy. Studia paedagogica, 16(1), 9-46.

VanMaanen, J. (1988). Tales of the field: On writing ethnography. Chicago: University of Chicago Press.

Verbiest, E. (2011). Developing professional learning communities. Příspěvek prezentovaný na konferenci AERA, New Orleans.

Wengraf, T. (2001). Qualitative research interviewing: Biographic, narrative and semistructured methods. London: Sage.

White, C., Woodfield, K., \& Ritchie, J. (2003). Reporting and presenting qualitative data. In J. Ritchie \& J. Lewis (Eds.), Qualitative research practice (s. 287-300). London: Sage.

Woods, P. (2006). Successful writing for qualitative research. Abingdon: Routledge.

\section{Autoři}

Mgr. Klára Šed’ová, Ph.D., Masarykova univerzita, Filozofická fakulta, Ústav pedagogických věd, Arna Nováka 1,602 00 Brno, e-mail: ksedova@phil.muni.cz

Mgr. Roman Švaříček, Ph.D., Masarykova univerzita, Filozofická fakulta, Ústav pedagogických věd, Arna Nováka 1, 60200 Brno, e-mail: svaricek@phil.muni.cz 


\title{
How to write qualitatively oriented research studies. Quality in qualitative research
}

\begin{abstract}
The aim of this methodological study is to define basic rules of a good qualitatively oriented empirical study, that means a research report presenting results of qualitative research which is intended for publication in a scientific journal. At the same time we share a distance from explicitly formulated quality criteria of qualitative research that might limit the autonomy of researcher when choosing own research methods and procedures. Our rules should therefore be seen as framework recommendations which enable authors to retain control over the quality of their own research. Presented rules apply to the four key areas of the research report: we address (1) theoretical part of the study, (2) description of the plan and conduct of the research, (3) outcomes of analysis and interpretation of data, and (4) language and style of writing the research report. Gradually we define 16 basic rules of quality writing that we interpret with the aid of methodological literature and annotated examples from published and unpublished qualitative studies. We believe that these rules can be recommended as basic guidelines to beginning authors of scientific texts intended for peer-reviewed journals.
\end{abstract}

Keywords: quality in qualitative research, qualitative research, quality criteria, academic writing

Janík, T., Pešková, K. et al. (2012). Školní vzdělávání: podmínky, kurikulum, aktéri, procesy, výsledky. Brno: Masarykova univerzita.

V knize jsou prezentovány nástroje umožňující realizovat výzkum v různých oblastech školního vzdělávání: podmínky, kurikulum, aktéŕi, procesy a výsledky. Autoři představují kategoriální systémy pro zkoumání: (a) holistického pojetí zdraví v učebnicích prvouky a školních vzdělávacích programech, (b) ideologičnosti v učebnicích občanské výchovy, (c) kurikulárních dokumentů v dějepise, (d) evropské dimenze v učebnicích dějepisu, (e) komunikačního pojetí literárního vzdělávání v čítankách, (f) profesního vidění u učitelů anglického jazyka, (g) genderových stereotypů a nerovností ve výuce anglického jazyka, (h) kompetence k učení v zeměpisu. V publikaci jsou dále prezentovány dotazníky pro zjištování a) inkluze ve škole, (b) sociálního klimatu třídy, (c) proenvironmentálního přesvědčení a postoje učitelů, (d) postavení nadaného žáka ve tř́dě, (e) řešení úloh žáky s vývojovou dyskalkulií, (f) autoregulace učení a (g) strategií učení v cizích jazycích. Představena jsou též schémata interview pro zjištování inklinace k biofilní koncepci vzdělávání učitelů a pro zjištování didaktických znalostí obsahu u učitelů a př́ípadová studie zaměřená na sebehodnocení žáků formou portfolia. 